
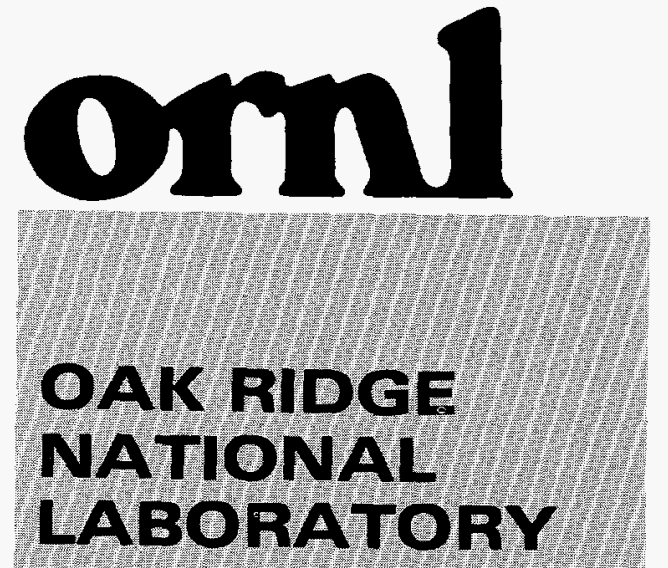

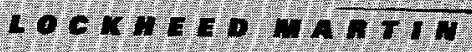
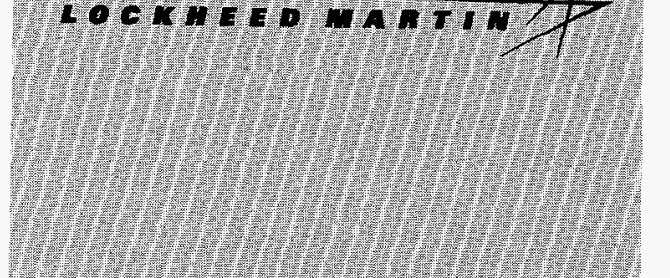

Whe
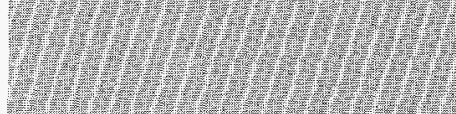

WMAGEO NWO OPEAATEO BY LOCKHEED WARTN ENEAGY RESEAROH CORPORMTION FOA THE UITEO STATES DEPANTUENT OF ENERGY

$$
\text { CRN/M- }-6215
$$

APPROVED FOR PUBLIC RELEASE

C/ORNL92-0103

CRADA Final Report

for

CRADA Number ORNL92-0103

\section{DEVELOPMENT OF GELCASTING FOR INDUSTRIAL APPLICATIONS}

\author{
S. D. Nunn \\ Oak Ridge National Laboratory \\ J. Ghinazzi \\ Coors Technical Ceramics Company \\ Prepared by the \\ Oak Ridge National Laboratory \\ Oak Ridge, Tennessee 37831 \\ managed by \\ Lockheed Martin Energy Research \\ Corporation \\ for the \\ U.S. Department of Energy \\ under contract DE-AC05-960R22464
}

APPROVED FOR PUBLIC RELEASE

UNLIMITED DISTRIBUTION 


\section{DISCLAMVER}

Portions of this document may be illegible in electronic image products. Imsges are produced from the best available original docoment 
CRADA Final Report

for

CRADA Number ORNL 92-0103

\title{
DEVELOPMENT OF GELCASTING FOR INDUSTRIAL APPLICATIONS
}

\author{
S. D. Nunn \\ Oak Ridge National Laboratory \\ J. Ghinazzi \\ Coors Technical Ceramics Company \\ Prepared by the \\ Oak Ridge National Laboratory \\ Oak Ridge, Tennessee 37831 \\ managed by \\ Lockheed Martin Energy Research Corporation \\ for the \\ U.S. Department of Energy \\ under contract DE-AC05-96OR22464
}

Research sponsored by the Advanced Automotive Materials Program,

DOE Office of Transportation Technologies, under contract DE-AC05-96OR22464 with Lockheed Martin Energy Research Corporation

Unlimited Distribution 


\section{CONTENTS}

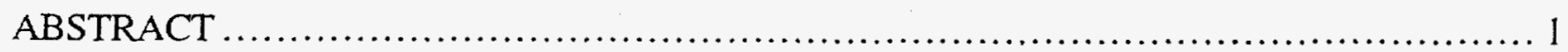

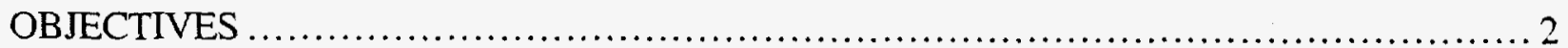

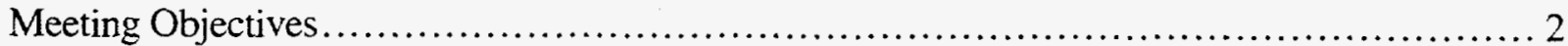

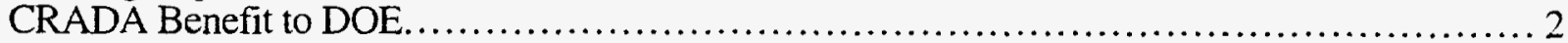

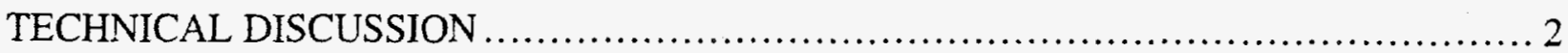

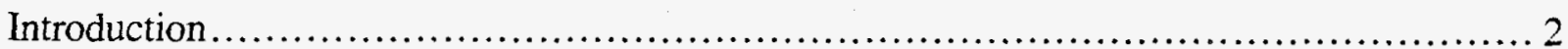

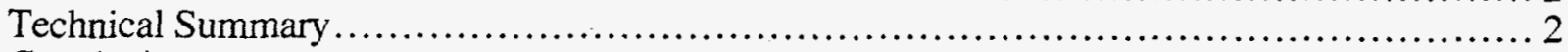

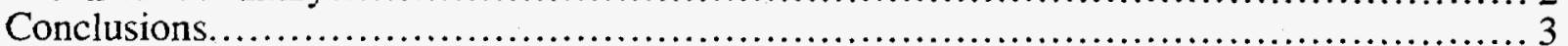

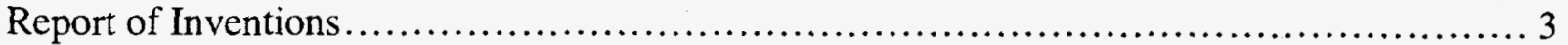

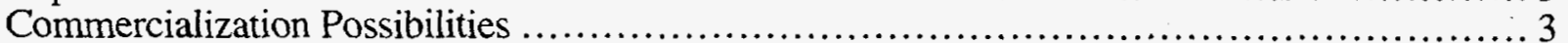

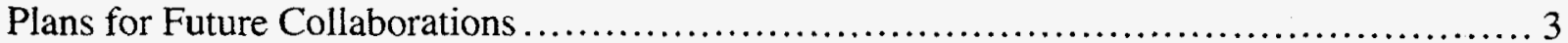

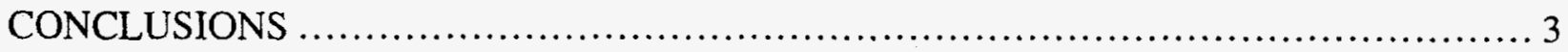

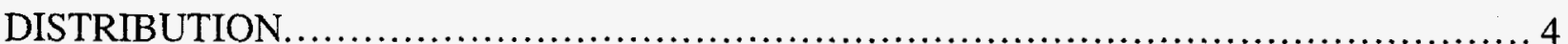




\section{ABSTRACT}

This Cooperative Research and Development Agreement (CRADA) was undertaken to assess the applicability of gelcasting for industrial production. The CRADA was amended to reflect development activity related to a new production component, an alumina Y-bar wafer support used in the silicon microcircuit manufacturing industry. This CRADA was terminated with no significant technical accomplishments completed. 


\section{OBJECTIVES}

The desired result of this CRADA was the successful demonstration of the gelcasting process for forming the Y-bar component using the Participant's alumina powder composition. Success would be judged by the quality of the castings and by the measurement of the properties of the gelcast and fired samples.

Meeting Objectives

The technical objectives of this CRADA were not met.

CRADA Benefit to DOE

Conduct of the research under this agreement was intended to increase understanding of the important ceramic powder characteristics and processing parameters which govern successful application of the gelcasting method.

\section{TECHNICAL DISCUSSION}

\section{Introduction}

The purpose of this Cooperative Research and Development Agreement (CRADA) was to assess the applicability of gelcasting for industrial production. The CRADA was amended to reflect development activity related to a new production component, an alumina Y-bar wafer support used in the silicon microcircuit manufacturing industry. The amended CRADA was approved and signed by all Parties.

The gelcasting process has been used successfully to form ceramic green bodies from numerous ceramic materials, including silicon nitride, silicon carbide, alumina, zirconia, etc. During these prior investigations, it has been observed that the gelcasting process needs to be tailored to each specific material. This is primarily due to the fact that gelcasting is a chemical process and any variation in the chemistry of the system will affect the characteristics of the process.

Coors Technical Ceramics would like to utilize the gelcasting process for production of ceramic components for microelectronics fabrication. In order to gain confidence in the applicability of the process using their proprietary alumina composition and to minimize the learning curve required for tailoring the process to their material, a cooperative research effort was proposed. ORNL provided the expertise and equipment for working with the gelcasting process, while Coors provided ceramic powder, specialty molds, and final processing and testing expertise to evaluate the gelcast material. The desired result of this CRADA was the successful demonstration of the gelcasting process for forming the Y-bar component using Coors' alumina powder composition.

\section{Technical Summary}

Five months after the amended CRADA was signed, the first lot of alumina powder for gelcasting trials was received from Coors. The powder was found to be unsuitable for gelcasting due to the presence of additives or impurities which constituted about $2.75 \mathrm{wt}$. \% of the powder. The powder was returned to Coors.

After discussions with all parties concerned, the Office of Technology Transfer sent a notice to Coors Technical Ceramics Company that all work on CRADA No. ORNL92-0103 would be discontinued. Reorientation in the sponsoring program's focus and the lack of substantial technical progress on the project were cited as the reasons for this action. 


\section{Conclusions}

This CRADA was terminated with no significant technical accomplishments completed.

Report of Inventions

There were no inventions developed under this agreement.

Commercialization Possibilities

There are no plans for commercialization.

Plans for Future Collaborations

There are no plans for future collaborations.

\section{CONCLUSIONS}

This CRADA was terminated with no significant technical accomplishments completed. 


\section{DISTRIBUTION}

1-2. Office of Scientific and Technical Information, P.O. Box 62, Oak Ridge, TN 37831

3. J. Ghinazzi, Coors Technical Ceramics Company, 1100 Commerce Park Dr., Oak Ridge, TN 37830

4. D. A. Haught, Department of Energy, EE-23, 1000 Independence Ave., Washington, DC 20585

5. R. L. Beatty, 4508 , MS-6089

6. R. A. Bradley, 4500S, MS-6161

7. D. F. Craig, $4500 S$, MS-6132

8. DOE-WFO, MS-G209

9. P. L. Gorman, 4500 N, MS-6269

10. D. R. Hamrin, 4500 N, MS-6285

11. M. A. Karnitz, 4515, MS-6065

12. R. J. Lauf, $4508, \mathrm{MS}-6085$

13. A. J. Luffman, 5002, MS-6416

14-24. S. D. Nunn, 4508, MS-6087

25. C. A. Valentine, $701 \mathrm{SCA}, \mathrm{MS}-8242$ 